УДК 81'33

DOI: $10.17277 /$ voprosy.2015.03.pp.235-239

\title{
SYNERGETIC APPROACH TO FOSTERING LEARNERS' INFORMATION AND LANGAUAGE AUTONOMY
}

\author{
G. K. Tleuzhanova, A. S. Khamzina \\ Buketov Karaganda State University, \\ Republic of Kazakhstan
}

\section{Reviewed by Doctor of Education, Professor R. P. Milrood}

Keywords: language education; language personality; linguistic and information self-dependence; professional linguistic education; self-organization; synergetic approach.

\begin{abstract}
This paper presents the process of learning a foreign language from the perspective of learner autonomy. The authors focus on the role of synergetic approach in the formation of language and information autonomy of students in higher education institutions of the Republic of Kazakhstan. Synergetic approach as the direction of interdisciplinary research in the formation of anguage and information autonomy of students reveals the general requirements, conditions and regularities of the learning process of students to a foreign language. All elements of the system interact consistently and lead to the process of self-organization. The process of learning a foreign language is integrated, systematic learning, with a student being self-governing, self-organizing and selflearning system.
\end{abstract}

The role of synergy has not been fully defined in the system of scientific knowledge. Synergetics is interpreted as a picture of worldview, scientific paradigm, or a separate discipline. Synergetics applied to interdisciplinary knowledge is a new phenomenon that makes us think that traditional disciplinary structure of scientific knowledge becomes unacceptable.

Synergetics as a model of self-organization brings new opportunities of strategies and stylistics of thinking, giving non-traditional approaches to multiple problems. Synergy sets a more general and wider problem of studying the emergence of self-organization as it occurs in natural processes.

Тлеужанова Гульназ Кошкимбаевна - кандидат педагогических наук, доцент, заведующая кафедрой «Европейские и восточные языки», e-mail: tleushanowa@inbox.ru; Хамзина Адина Сериковна - магистрант, Карагандинский государственный университет им. академика Е. А. Букетова, Республика Казахстан. 
Primarily, objects appear completely independently, and their movement shows no mutual ordering. This initial condition is often characterized by the concept of "chaos" and "disorder". Then critical values coming from external energy or information are based on the interaction between objects, which begin to participate in a concerted, collective motion.

Chaos is replaced by order, giving rise to some structure that sets constant relations between the components, with the former independent objects being transformed into elements of an ordered system. Consequently, synergetics is science of complex systems that interact with the outside environment, which manifests a collective multi-particulate action of dissimilar elements, leading to irreversible, non-linear, non-equilibrium behavior of the system, and its development through a cascade of relatively stable states.

Synergetic approach is a methodological orientation in cognitive and practical activities involving the use of combination of ideas, concepts and methods in research and management of open nonlinear self-organizing systems. Synergetics has reinvented the processes of education and reveals its nonlinear character. In our case it is the non-linear character of the process of education, in particular, the development of meaningful attitude of students to learning a foreign language. Synergetic implies an adequate understanding of the essence of the process of language acquisition and its optimal organization.

However, we do not mean a simple application of the principles and laws of synergy to the analysis of the processes taking place in education, to foreign language teaching and its introduction in the educational process. In practice of foreign language teaching the methodology of synergy can be applied to transferring from chaos to a certain order. In this regard, we are referring to the study of factors such as the role of a teacher and student personality, the freedom to choice, etc.

A pedagogical process is included into an integrated global process of selforganization and thus subject to its objective laws. Therefore, the process of learning foreign languages is a self-governing process controlled from within by its laws and regularities. The existing versions of the definition of synergy based on such properties of the system as non-linearity, coherence, openness, are really necessary for understanding of self-organization of different systems. In education, it is the personality of a student and a teacher, a group of students and a community of teachers, an educational institution and its environment.

The process of learning a foreign language is considered from the standpoint of synergy as a self-learning management of the individual. The need for self-development of students in the process of learning a foreign language is the basis of their cognitive activity. The teacher also evaluates the correctness or incorrectness of the implementation of educational tasks, organizes the learning process and transmits the information to students [1, p. 47].

It is a universal fact that the process of learning a foreign language means cultural exchange. Immersion into a language environment in the initial stage represents chaos. The process of language learning contributes to the generation of order. Bifurcation effect occurs when there is a contradiction between the clarity of communication problems and lack of linguistic resources to address them. Chaotic movements into system are characterized by the tolerance of the 
substructures system. Chaos also occurs in the process of joint (group) work and involves bringing order to chaotic thoughts and using a synergetic approach to the mental integrated strategy. Chaos is a problem that must be resolved. Communications within the group (open system), between the substructures (learners) are essential in the stage of transition to order.

Therefore synergistic understanding of the learning process provides harmonious relations and tolerance among the study group participants (open system). The possible fluctuations contribute to the need to organize and change the system [2].

If a group of students is regarded as a self-organizing system, the participation of a teacher will present a certain fluctuation. It should be noted that in the synergistic educational paradigm the role of a teacher is that of a facilitator, and does not imply knowledge dissemination, assessment of the correctness of judgments, observation of the reasoning, and changeover from one level to another. As a result, understanding becomes deeper, versatile, incentives to learning creates energy of the group without pressure from the teacher.

Development of linguistic and information self-dependence of students of higher educational institutions leads to the development of their personality through language acquisition as a means of information exchange with the environment in order to transform the world and themselves with selforganization.

This process refers to an individual and his culture, directs students' personality, where the language has a powerful influence on thinking of man (M. M. Bakhtin), it is not only a means of knowledge dissemination, but also an instrument of intellectual activity (V. P. Zinchenko).

Synergetic approach is aimed at shaping a language student personality, which is the subject of intercultural communication in the course of professional linguistic education, a set of cultural and professional competencies that provide a specific set of values, personal qualities and creative business thinking, universal ways of raising awareness of their own intercultural worldview. Intercultural communication is closely linked with cultural identity and humanization of relations with people of different ethnic community. The synergistic approach focuses on the consistency of interaction of structural elements; the principle of self-organization makes it possible to develop the linguistic personality of a student, harmonize public relations, change the priority needs and interests, values, motives and purposes of an individual.

The synergistic approach is based on a multidimensional complexity of processes, objects and phenomena that are in constant development. It has become a strong methodological basis for pedagogical research, especially, to the study of complex and open systems, such as education. On the philosophical level S. K. Gural and S. A. Lamzin regard it as a scientific field, contributing to the creation of didactic conditions for professional training in the field of foreign language education.

The synergetic approach allows investigating the problems of education from the perspective of transparency, non-linearity, self-organization and selfdevelopment. In the formation of linguistic and information self-dependence of students at foreign language lessons, the maximum synergistic effect can be 
achieved by using such forms as "brainstorming", "cinquains", creating "mind maps" and other new teaching techniques.

Brainstorming is kind of group work, that involves generating lots of ideas. From the beginning a teacher encourages students to think about the problem and express their thoughts. All statements are written on the board, no matter what students say, or whether it matches teacher's expectations. It is necessary to get students involved in the activity by providing adequate support and encouragement. The most important at the initial stage is to avoid criticism and comments. Otherwise, student might get discouraged from expressing their ideas. Then the ideas are systematized, discussed and summarized. The teacher provides students with a range of structures and vocabulary necessary for the assignment task. This technique develops creative and associative thinking, enhances memorization of useful words and phrases and removes the language barrier.

Cinquain is a form of writing, reflecting the ability of students to summarize information, express complex ideas in a few words. Basically, it is a poem of five lines. It usually resembles a table where the first line is the topic or subject (one noun), the second line describes the subject (two adjectives or participles), the third line characterizes the action of the subject (3 verb), the fourth line contains a phrase of four meaningful words expressing the author's attitude to the subject, and the fifth line is a synonym summarizing or expanding the meaning of the topic or subject (one word).

Intellectual cards came up with Tony Buzan, a psychologist, a specialist in the field of self -development of memory, and thinking. Intellectual cards are a natural expression of how the child's brain functions. In the literal sense, it is a mind map, which involves direct memory, associative thinking and creative thinking. Intellectual cards can be used at any stage of the lesson.

Mind maps can be used for brainstorming, learning new vocabulary, summarizing and retelling, summarizing all topics that need to be repeated or are currently being studied, i.e. for activation of verbal and cogitative activity $[3,4$, p. 634].

In such a way the synergistic approach can cover both linguistic and professional subject areas. The key concepts of synergy - self-organization and self-management - are the main characteristics of the educational process. The development of linguistic and information self-dependence of students from the perspective of the synergistic approach, being the basis of cognitive activity, implies emphasis on self-learning and self-development of a future specialist.

\section{References}

1. Glazun M.A., Starostenkov M.D. (2006). Fundamental'nye issledovaniya [Fundmental studies], no. 5, pp. 47-48.

2. Gural' S.K., Obdalova O.A. (2011). Yazyk i kul'tura [Language and culture], no. 4, pp. 90-94.

3. Fedotova M.G., Yaroslavova E.N., available at: http://kafedraforum.narod.ru/index/0-47

4. Volkova O.M. (2014). Molodoi uchenyi [Young Researcher], no. 6, pp. 631634. 


\section{Список литературы}

1. Глазун, М. А. Синергетика и проблемы обучения студентов иностранному языку / М. А. Глазун, М. Д. Старостенков // Фундамент. исследования. 2006. - № 5. - С. 47-48.

2. Гураль, С. К. Синергетическая модель развития образовательного пространства / С. К. Гураль, О. А. Обдалова // Язык и культура. - 2011. - № 4. C. $90-94$.

3. Федотова, М. Г. Семиотико-синергетический подход к развитию профессионально-ориентированной иноязычной коммуникативной компетентности обучающися в непрерывном иноязычном образовании [Электронный ресурс] / М. Г. Федотова, Е. Н. Ярославова. - Режим доступа: http://kafedraforum.narod.ru/index/0-47 (дата обращения: 27.07.2015).

4. Волкова, О. М. Синергетические принципы как основа методологической парадигмы иноязычного образования в школе / О. М. Волкова // Молодой ученый. - 2014. - № 6. - C. 631 - 634 .

\section{Синергетический подход к формированию языковой и информационной самостоятельности студентов}

\section{Г. К. Тлеужанова, А. С. Хамзина}

Карагандинский государственный университет им. академика Е. А. Букетова, Республика Казахстан

Ключевые слова: профессиональное лингвистическое образование; синергетический подход; языковая личность; языковая и информационная самостоятельность; языковое образование, самоорганизация.

Аннотация: Рассмотрены проблемы организации процесса изучения иностранного языка с точки зрения синергетического подхода к формированию языковой и информационной самостоятельности студентов вузов Республики Казахстан. Синергетический подход как одно из направлений междисциплинарных исследований позволяет сформулировать общие требования, условия и закономерности процесса обучения студентов иностранному языку. Данный процесс представлен как интегрированная система образования, включающая элементы самоуправления, самоорганизации и самообучения студента.

(C) Г. К. Тлеужанова, А. С. Хамзина, 2015 